\title{
A NEW GENUS OF THE FAMILY LOCUSTOPSIDAE (INSECTA, CAELIFERA) IN THE SANTANA FORMATION (LOWER CRETACEOUS, NORTHEAST BRAZIL)
}

\author{
Rafael Gioia MARTINS-NETO
}

\begin{abstract}
Departamento de Biologia da Faculdade de Ciências e Letras da Universidade de São Paulo, Campus de Ribeirão Preto, and in collaboration with the Universidade de Guarulhos, SP. Av. Bandeirantes, 3900, 14040-901. Ribeirão Preto SP Brasil e-mail: mtnsneto@ffclrp.usp.br
\end{abstract}

Martins-Neto, R.G. 1998. A new genus of the family Locustopsidae (Insecta, Caelifera) in the Santana Formation (Lower Cretaceous, Northeast Brazil). [Un nuevo género de la familia Locustopsidae (Insecta, Caelifera) de la Formación Santana (Cretácico Inferior, Noreste de Brasil)]. Revista Española de Paleontología, 13 (2), $133-138$. ISSN 0213-6937.

\begin{abstract}
The new genus Cratozeunerella (Caelifera, Locustopsidae) and three constituent new species, C. neotropica n. sp., C. nordestina n. sp., and C. amedegnatoi n. sp., are described from the Santana Formation (Lower Cretaceous) of northeastern Brazil. The family Locustopsidae was hitherto represented in the Brazilian Cretaceous by two other genera: Zessinia Martins-Neto and Locustopsis Handlirsch, suggesting that the group was most successful in the Southern Hemisphere during Cretaceous times. This family is typical of the Mesozoic and the oldest record is from the Lower Triassic of Australia. The family is represented now by nine genera including more than forty species. Thirty in the genus Locustopsis Handlirsch Handlirsch, which is known from Jurassic rocks in Europe and Asia as well as from Cretaceous rocks in Asia, Africa and Brazil.
\end{abstract}

Keywords: Insecta, Locustopsidae, Cratozeunerella n. gen., Lower Cretaceous, Santana Formation, Brazil.

\section{RESUMEN}

Se describe el nuevo género Cratozeunerella (Caelifera, Locustopsidae) con las nuevas especies C. neotropica n. sp., C. amedegnatoi n. sp. y C. nordestina n. sp. de la Formation Santana (Cretácico Inferior, nordeste de Brasil). Hasta ahora, la familia Locustopsidae era conocida en el Cretácico brasileño por dos géneros: Zessintia MartinsNeto y Locustopsis Handlirsch, lo que sugiere que el grupo alcanzó un gran éxito en el Hemisferio Sur durante el Cretácico. Esta familia es típica del Mesozoico y su registro más antiguo proviene del Triásico Inferior de Australia. En la familia se incluyen actualmente nueve géneros y más de cuarenta especies, treinta de ellas pertenecientes al género Locustopsis Handlirsch, conocido de materiales jurásicos de Europa y Asia, y también de materiales cretácicos de Asia, África y Brasil.

Palabras clave: Insecta, Locustopsidae, Cratozeunerella n. gen., Cretácico Inferior, Formación Santana, Brasil.

\section{INTRODUCTION}

The family Locustopsidae was hitherto represented in the Brazilian Cretaceous by two genera and five species (Martins-Neto, 1990). Here, three new species of a new genus are described considerably extending both the geographical and the stratigraphical distribution of the family. The group is surprisingly abundant and diverse (at the generic taxonomic level), suggesting that it was most successful in the Southern Hemisphere during
Cretaceous times. In this paper, a new genus closely related to Zeunerella Sharov, 1968 is described. The fossil insects described here are represented by relatively complete, well preserved specimens, which came from the crato Member, the lowest unit of the Santana Formation (Araripe Basin, Northeast Brazil, Lower Cretaceous, Upper Aptian/ Lower Albian). The local palaeontology and stratigraphy have been summarized in Martins-Neto (1991; 1996). The morphological nomenclature follows Kukalova-Peck (1991). 


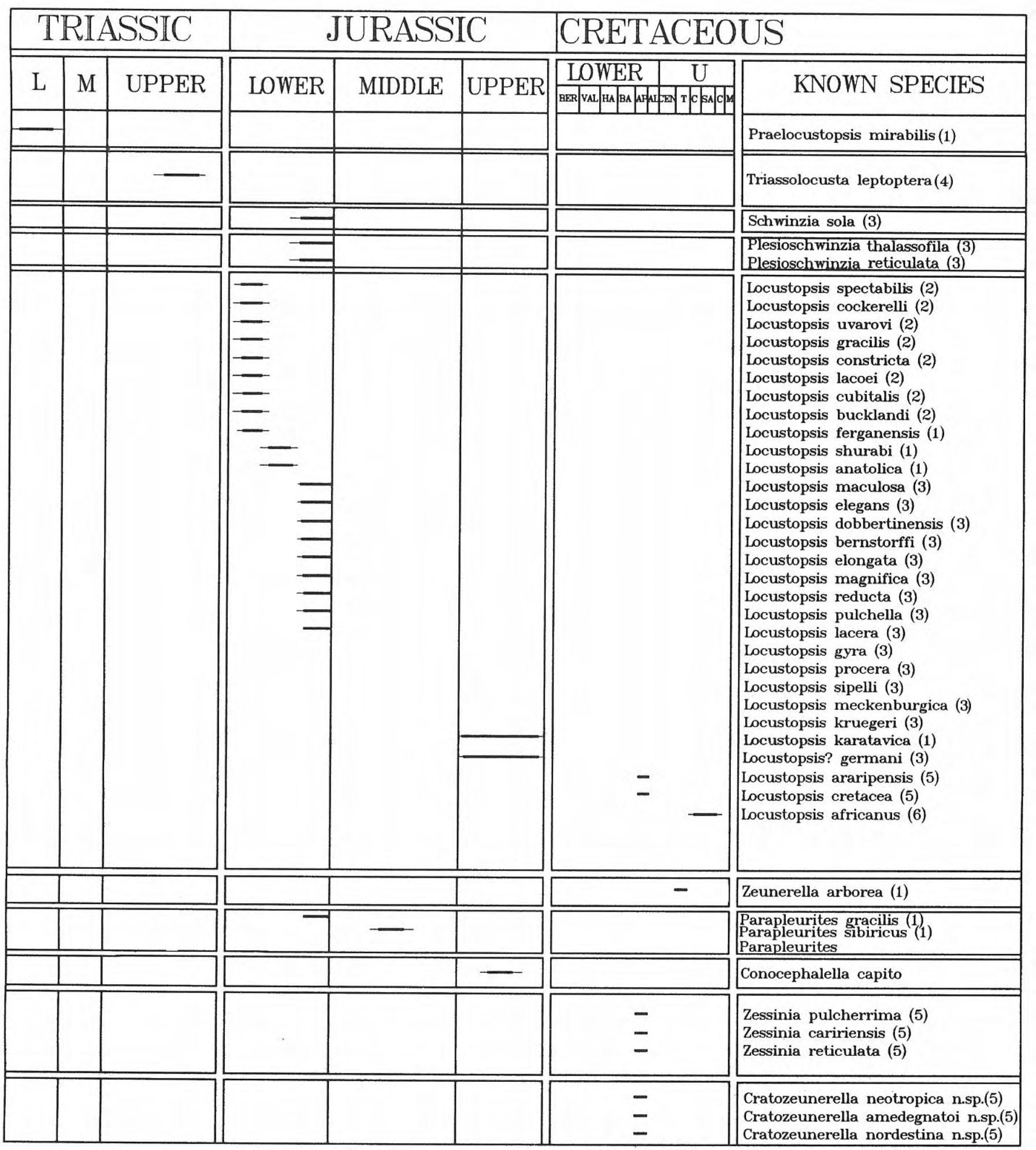

Figure 1. Distribution of the genus of the family Locustopsidae in the geological record, based in Zessin (1983), MartinsNeto (1990) and Ansorge (1991). 1: Asia; 2: England; 3: Germany; 4: Australia; 5: Brazil and 6: Africa.

\section{SYSTEMATIC PALAEONTOLOGY}

Family Locustopsidae Handlirsch, 1906

Despite some major reviews, the family Locustopsidae is still in need of much discussion because it includes genera with inconsistently resolveol phylogenetic relations. Thus, along with advances in research on the group in the Santana Formation, the phylogenetic relations of the genera will be discussed. Nowadays, nine genera are accepted: Praelocustopsis Sharov (1 sp., Triassic, Australia); Triassolocusta Tillyard (1 sp., Triassic, Australia); Schwinzia Zessin (1 sp., Lower Jurassic, Germany); Plesioschwinzia Zessin (2 sp., Lower 

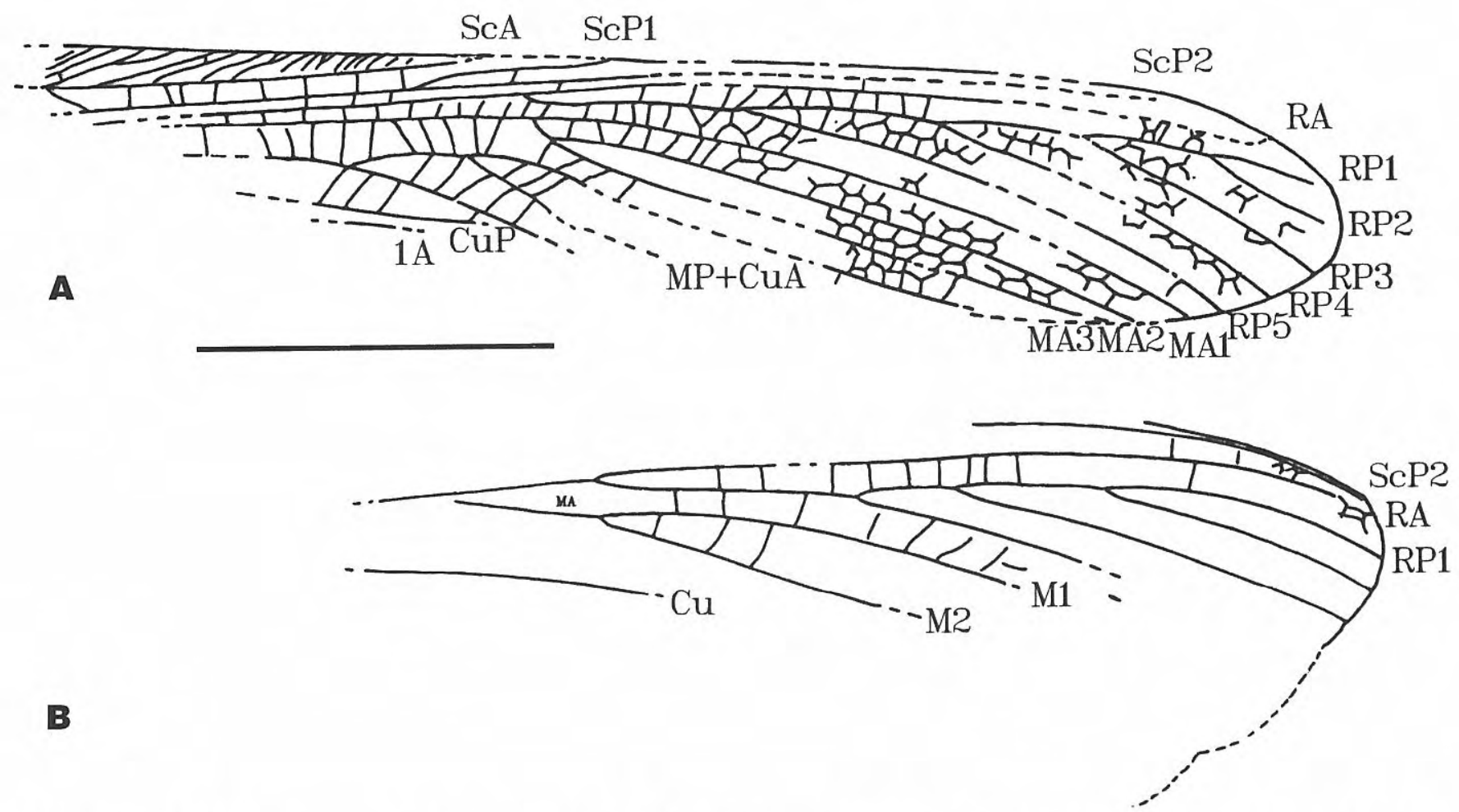

Figure 2. A-B) Cratozeunerella neotropica n. sp., holotype, camera lucida drawing of A) fore-wing; B) hind-wing. Scale bar 5mm. Terminology: A, anal; CuA cubital anterior; CuP cubital posterior; MA, media anterior; MP media posterior; RA, radial anterior; RP, radial posterior; ScA, subcostal anterior; $\mathbf{S c P}$, subcostal posterior.

Jurassic, Germany); Locustopsis Handlirch (30 sp., Lower Jurassic - Cenomanian Europe, Asia, Africa and Brazil); Parapleurites Brauer, Redtenbacher \& Gangbauer (2 sp., Middle Jurassic, Siberia); Conocephalella Strand (1 sp., Upper Jurassic, Germany); Zessinia Martins-Neto (3 sp., Aptian/Albian, Brazil) and Zeunerella Sharov (1 sp., Cenomanian, Mongolfia) (see Fig. 1). Ansorge (1991) described a new Locustopsis species from Egypt, (Lower Cretaceous), based only on the hind-wing morphology, which was, however, unlike comparable material from Brazil. The Brazilian and African species are the only record of the group in the Mesozoic of Southern Hemisphere. Lewis (1974) published a short note about four specimens of fossil grasshoppers from the Ruby River Basin (Oligocene) in Southwestern Montana, relating them to the genus Zeunerella Sharov. However, these specimens have not received a formal treatment discussing this identification. Gomes Pallerola, in Ansorge (1991) noted possible locustopsids in the Cretaceous sediments from Montsech, Spain.

\section{Cratozeunerella n. gen.}

Type-species: Cratozeunerella neotropica $\mathrm{n}$. sp. designated here with.

Derivatio nominis: Crato, the regional unit, and Zeunerella, the most similar genus.

Diagnosis (see Fig. 2 for abbreviations)
Similiar to Zeunerella Sharov, 1968 in possessing ScA long, reaching almost to the origin of RP. Branches of RP not reaching anterior margin; MA2 originating on the base of the posterior branch of MA1. Base of CuA and $\mathrm{CuA} 2$ in the form of a single curved vein, the distal third of which branches anteriorly into a bifurcated MP+CuA1. Cratozeunerella n. gen. Differs from Zeunerella Sharov in the costal area between $\mathbf{C}$ and $\mathbf{S c A}$, being basally narrower than in its distal part and ScA in Zeunerella, but broader and with the subcostal field with cross-veins in Cratozeunerella n. gen.

\section{Discussion}

This genus is separated from Zeunerella Sharov by the shape of the costal and subcostal areas: the costal area between $\mathbf{C}$ and $\mathbf{S c A}$ is basally narrower than in its distal part in Zeunerella Sharov. This unique character is probably an autapomorphy within this family. This character is not shared by Cratozeunerella n. gen., strongly suggesting that Cratozeunerella n. gen. is a closely related new genus. Cratozeunerella $\mathrm{n}$. gen. differs from all locustopsids having $\mathbf{S c P}$ with only one branch.

\section{Cratozeunerella neotropica $\mathrm{n}$. $\mathrm{sp}$. Figs. 2, 3A}

Derivatio nominis: from the Neotropics.

Holotype: UnG-030, housed in the Palaeontological Collection of the Geosciences Department, Guarulhos 

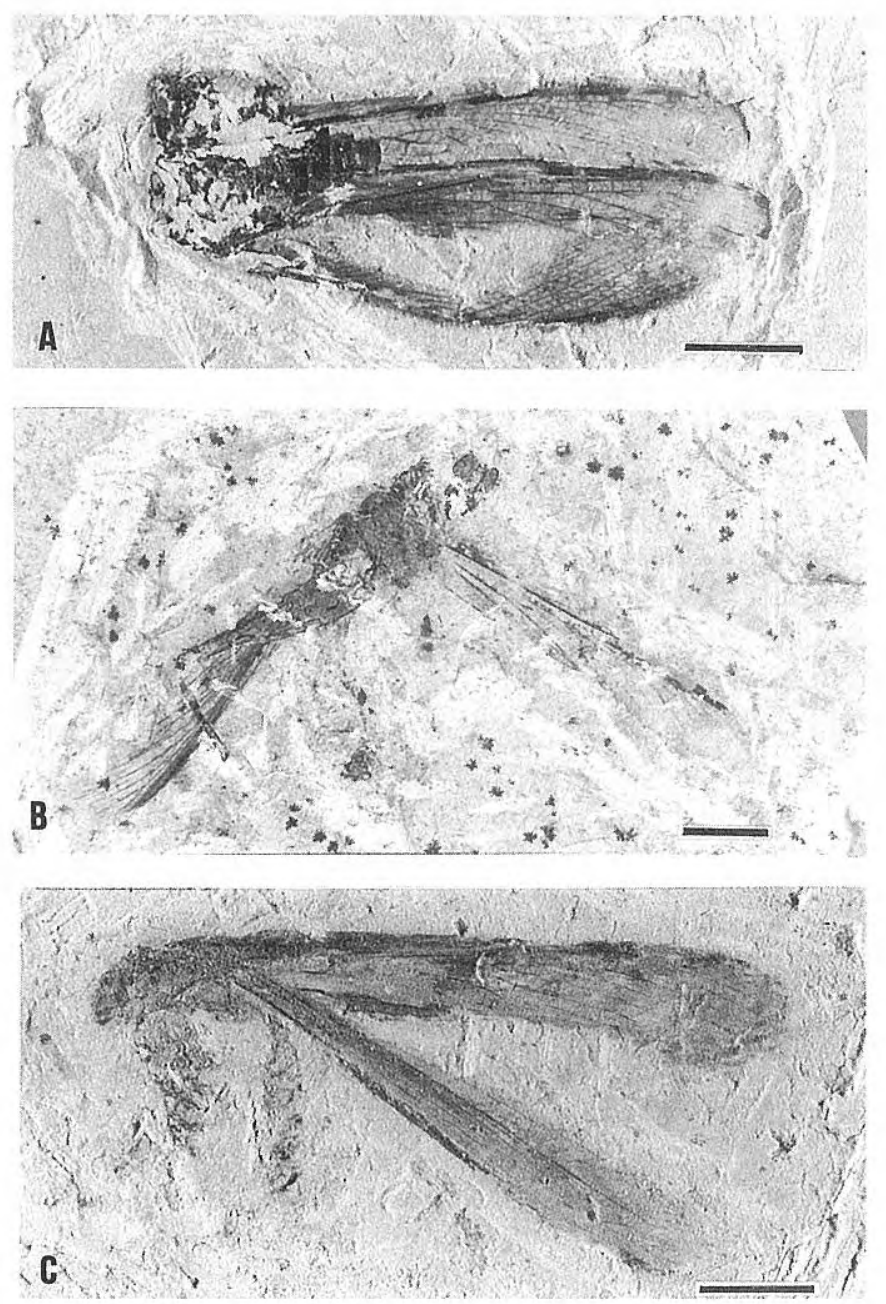

Figure 3. A) Cratozeunerella neotropica n. sp., holotype; B) Cratozeunerella amedgnatoi n. sp., holotype; C) Cratozeunerella nordestina n. sp., holotype. Scale bar $5 \mathrm{~mm}$.

University (UnG), São Paulo, Brazil. Only the holotype is known.

\section{Locus and stratum-typicum}

Outcrop of Tatajuba farm (Martins-Neto, 1996) Santana do Cariri, Cear. State, Northeast Brazil. Upper part of the Crato Member, laminated limestone level, lowest unit of the Santana Formation, Lower Cretaceous (Upper Aptian/Lower Albian) Araripe Basin.

\section{Diagnosis}

As for the genus. Fore-wing about $23 \mathrm{~mm}$ long and $3.5 \mathrm{~mm}$ wide. RP with five branches. Hind-wing: $\mathbf{R P}$ with four branches; MA forks opposite the origin of RP.

\section{Description}

Fore-wing (Fig. 2A) $23.1 \mathrm{~mm}$ long and $3.4 \mathrm{~mm}$ maximal width. ScA long, ending in the costal margin one third of the distance along its length, and filled by several pectinate branches. Costal area between $\mathbf{C}$ and $\mathbf{S c A}$ wide at its proximal position, narrowing toward costal margin. ScP1 is a short, sigmoidal vein; ScP2 possibly long, curved, ending in the apical margin (only the basal part is preserved). RA long, slightly curved, distally not preserved; the origin of RP is anterior to the mid-length level of the tegmen, slightly posterior to the end of $\mathbf{S c A}$, divided into five branches. Fork of MA opposite the origin of RP; MA1 long, slightly curved; MA2 and MA3 with the same length, slightly curved too; $\mathbf{M P}+\mathbf{C u A}$ three-branched, the more proximal one longer; only the bases of $\mathbf{M P}+\mathbf{C u A} \mathbf{2}$ and $\mathbf{M P}+\mathbf{C u A} \mathbf{3}$ are preserved; the preserved part of $\mathbf{C u P}$ is quite straight; $\mathbf{1 A}$ poorly preserved. Hind-wing venation (Fig. 2B): RP with four branches; MA forks opposite the origin of RP with two branches of the same length.

\section{Discussion}

Similar to Zeunerella arborea Sharov, 1968 principally in $\mathbf{M P}+\mathbf{C u A}$ morphology (fore-wing). Cratozeunerella neotropica n. sp. differs from $Z$. arborea, however, by having five branches of RP (there are three branches of $\mathbf{R P}$ and three intercalar veins in $Z$. arborea). Another distinctive character is the fork of $\mathbf{M}$ in the hind-wing, opposite the origin of RP in $C$. neotropica n. sp., but near of the origin of $\mathbf{R P}$ in $Z$. arborea. Furthermore, $C$. neotropica n. sp. has a supplementary branch of $\mathbf{R P}$ in the hind-wing.

\section{Cratozeunerella amedegnatoi $\mathrm{n}$. $\mathrm{sp}$. Figs. 3B, 4A}

Derivatio nominis: named in honour of the French Caelifera specialist, Dr. C. Amedegnato, Museum National díHistoire Naturelle (Paris).

Holotype: CD-I-127, Desirée Collection (CD), housed in Departamento Nacional da Produção Mineral (DNPM) Palaeontological Collection. Only the holotype is known.

\section{Locus and stratum-typicum}

Locality unknown, probably near Santana do Cariri in the Cear-State. Crato Member, laminated limestone level, lowest unit of the Santana Formation. Lower Cretaceous (Upper Aptian/Lower Albian). Araripe Basin.

\section{Diagnosis}

Fore-wing about $25 \mathrm{~mm}$ long and $3 \mathrm{~mm}$ wide; $\mathrm{MP}+\mathrm{CuA}$ two-branched.

\section{Description}

Fore-wing (Fig. 4A) $24.9 \mathrm{~mm}$ long and $3.2 \mathrm{~mm}$ wide; ScA long reaching the costal margin one third of the distance along the wing base, with few cross-veins. ScP1 relatively long and sigmoid; $\mathbf{S c P 2}$ long, curved, ending in the apical margin with few preserved cross-veins; RA long, slightly curved: origin of $\mathbf{R P}$ at same level as end of $\mathbf{S c P}$, divided into five branches. Fork of MA anterior to the origin of the RP vein. MA1 long, curved; MA2 slightly longer than MA3; $\mathbf{M P}+\mathbf{C u A}$ two-branched: $\mathbf{M P}+\mathbf{C u A}+\mathbf{2}$ longer, angulated in its middle length (vestigial branch?); $\mathbf{M P}+\mathbf{C u A 3}$ curved. $\mathbf{C u P}$ distally fused with $\mathbf{M P + C u A 3} ; \mathbf{1 A}$ very near to $\mathbf{C u P}$, parallel to it; $\mathbf{2 A}$ and $\mathbf{3 A}$ partially preserved, both parallel to $\mathbf{1 A}$ and $\mathbf{C u P}$. 

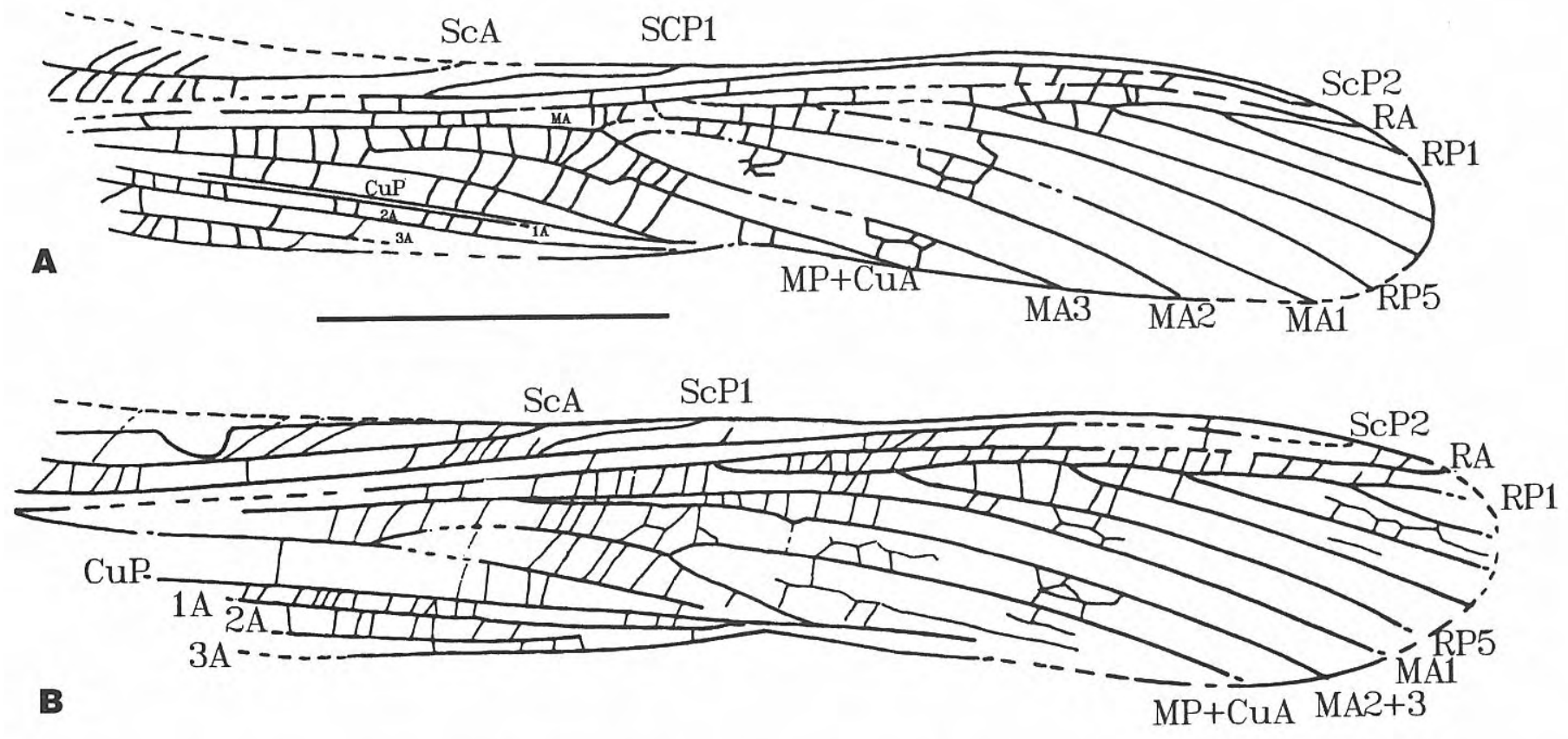

Figure 4. A) Cratozeunerella amedegnatoi n. sp. holotype, camera lucida drawing of fore-wing; B) Cratozeunerella nordestina $\mathrm{n}$. sp., holotype, camera lucida drawing of fore-wing. Symbols as for Fig. 2. Scale bar $5 \mathrm{~mm}$.

\section{Discussion}

Similar to Cratozeunerella neotropica $\mathrm{n}$. sp., differing however in $\mathbf{M P}+\mathbf{C u A}$ being three-branched in $C$. neotropica n. sp., but two-branched in $C$. amedegnatoi $\mathrm{n}$. sp. Additionally, the RP origin is opposite the end of ScP1, unlike $C$. neotropica $\mathrm{n}$. sp. where the origin of $\mathbf{R P}$ is anterior to the apex of the ScP1. The fore-wing of $C$. amedegnatoi $\mathrm{n}$. sp. is slightly longer and narrower than in C. neotropica $\mathrm{n}$. $\mathrm{sp}$.

\section{Cratozeunerella nordestina $\mathrm{n}$. $\mathrm{sp}$. Figs. 3C, 4B}

Derivation nominis: latinized form of northeast.

Holotype: UnG-31 housed in the Palaeontological Collection of the Geosciences Department, Guarulhos University (UnG), S,,o Paulo, Brazil. Only the holotype is known.

\section{Locus and stratum-typicum}

The same as for $C$. netropica $\mathrm{n}$. sp.

\section{Diagnosis}

Fore-wing $25 \mathrm{~mm}$ long and $4.5 \mathrm{~mm}$ wide. $\mathbf{M P}+\mathbf{C u A}$ three-brached and RP origin opposite from ScP1; MA; two-branched.

\section{Description}

Fore-wing (Fig. 4B) $25 \mathrm{~mm}$ long and $4.5 \mathrm{~mm}$ wide. ScA, ScP2 and RA as for previously described species. ScP1, is a relatively short vein, slightly curved. RP origin at the same level as the end of ScP1, with five branches; MA forks at same level as the end of $\mathbf{S c A}$, anterior to the level of $\mathbf{R P}$ and
ScP1 origins. MA two-branched; MA1, long and curved, ending at apical margin; MA2+3 long, shorter than MA1, curved, ending at the limit of the apical margin; $\mathbf{M P}+\mathbf{C u A}$ three-branched; $\mathbf{M P}+\mathbf{C u A} \mathbf{1}+\mathbf{2}$ long and curved; $\mathbf{M P + C u A} \mathbf{1}$ longer than the others, MP+CuA2 much shorter than $\mathbf{M P}+\mathbf{C u A 1}, \mathbf{M P}+\mathbf{C u A 3}$ slightly sigmoid; CuP quite straight; $\mathbf{1 A}$ fused distally with $\mathbf{C u P} ; \mathbf{2 A}$ slightly curved; $\mathbf{3 A}$ not preserved.

\section{Discussion}

Similar to $C$. neotropica n. sp., in the three-branched $\mathbf{M P}+\mathbf{C u A}$; similar to $C$. amedegnatoi $\mathrm{n}$. sp. in the origin of RP at the same level as the end of ScP1; $C$. nordestina n. sp. differs, however, by having MA two-branched (it is three-branched in $C$. neotropica n. sp. and $C$. amedegnatoi $\mathrm{n}$. sp.). Additionally the $\mathbf{M P}+\mathbf{C u A}$ branches of $C$. nordestina $\mathrm{n}$. sp. are more divergent than in the other species and $\mathbf{S c P 1}$ is relatively shorter.

\section{Remarks}

The MA2+3 branch of $C$. neotropica $\mathrm{n}$. $\mathrm{sp}$. has just a break at around one third of its length, which is significant. This break is probably the vestigial point of the fork of MA, from which the true MA2 and MA3 veins originated. This particular character, if consistent in other specimens, probably could justify the creation of a new genus for this species.

\section{AKNOWLEDGMENTS}

The author is grateful to Dr. C. Amedegnato (Muséum National d'Historie Naturelle, Paris) and Dr. A. Ponomarenko (Russian Academy of Sciences, Moscow) for suggestions Dr. Peter W. Skelton (Open University) for 
correction of the English. Dr. Xavier Martínez-Delclós (Universitát de Barcelona) and Dr. André Nel (Muséum National d'Histoire Naturelle, Paris) are especially thanked for critical review and suggestions. This paper is a contribution to IGCP Project 381, South Atlantic Mesozoic Correlations.

\section{REFERENCES}

Ansorge, J. 1991. Locustopsis africanus n. sp. (Saltatoria, Caelifera) aus der Unterkreide SW-Agyptens. Neues Jahrbuch Geologie und Palaontologie, Mh, 4, 205-212.

Kukalova-Peck, J. 1991. Fossil History and the Evolution of Hexapod Strucutures. In: The insects of Australia, cap. 6. Ed. C.S.I.R.O., Melbourne, University Press, 141-179.

Lewis, S.E. 1974. Four Specimens of Fossil Grasshoppers (Orthoptera: Caelifera) from the Ruby River Basin (Oligocene) of Southwestern Montana. Annals of the Entomological Society of America, 67, 523-524.

Martins-Neto, R.G. 1990. The family Locustopsidae
(Insecta, Caelifera) in the Santana Formation (Lower Cretaceous, Northeast Brazil), I - Description of two new species of the genus Locustopsis Handlirsh and three new species of the genus Zessinia n. gen. In: Simpósio sobre a Bacia do Araripe e Bacias Interiores do Nordeste, Crato, 1990, Atas, 1, 277-291.

Martins-Neto, R.G. 1991. Sistemática dos Ensifera (Insecta, Orthopteroida) da Formação Santana, Cretáceo Inferior do Nordeste do Brasil. Acta Geológica Leopoldensia, 32, 3-162.

Martins-Neto, R.G. 1996. New mayflies (Insecta, Ephemeroptera) from the Santana Formation (Lower Cretaceous), Araripe Basin, Northeastern Brazil. Revista Española de Paleontología, 11, 127-192.

Sharov, A.G. 1968. Filogenia orthopteroidenuch nasekomych. Trudy Paleontologiceskogo Instituta Nauka, 118, $1-251$.

Zessin, W. 1983. Revision der mesozoishen Familie Locustopsidae unter Ber, cksichtigung neuer Funde (Orthopteroida, Caelifera). Deustsche Entomological Zeistchrift, N.F., 30 (1/3), 173-237. 